\title{
Kajian Produksi Biogas Skala Laboratorium Dengan Inokulum Konsorsium Alami Metanogen Dari Lumpur Waduk Jatiluhur Dalam Substrat Bungkil Jarak Pagar (Jatropha curcas L)
}

\section{Study Of Methane Production By Methanogenic Consortium Bacteria From Sediment Jatiluhur Dam With A Substrate Of Jatropha Curcas Seed Pressed Cake (Jatropha Curcas L)}

\author{
Yati supriatin(1), I.Nyoman.P.A(2), Rani Handriani(3) \\ Prodi Kimia Sekolah Tinggi Analis Bakti Asih \\ SITH Bioteknologi ITB \\ Prodi Analis Kesehatan Sekolah Tinggi Analis Bakti Asih \\ Email :yatisupriatin@gmail.com
}

\begin{abstract}
Abstrak
Kajian produksi biogas dengan substrat bungkil Jarak pagar (Jatropha curcas L) skala reaktor 2,5 liter ini bertujuan untuk memperoleh kondisi optimum sumber inokulum untuk produksi biogas dengan substrat bungkil jarak pagar sebagai langkah awal untuk pengembangan biogas skala aplikasi. Penelitian diawali dengan penapisan sumber inokulum yang berasal dari kotoran sapi, sedimen waduk, dan cairan rumen sapi. Setelah diperoleh sumber inokulum dilanjutkan pada tahap perlakuan menggunakan substrat bungkil jarak dengan rasio $\mathrm{C} / \mathrm{N}$ 12,6 serta substrat campuran bungkil jarak dan limbah tapioka dengan rasio C/N 15 menggunakan 3 variasi konsentrasi inokulum yaitu 5\%, 10\%, 20\% dengan 4 pengulangan. Substrat bungkil Jarak pagar dengan rasio C/N yang sudah diatur disterilkan terlebih dahulu sebelum diberi inokulum starter, lalu diamati selama 70 hari dengan mengukur kandungan gas metana. Hasil penapisan sumber inokulum menunjukkan bahwa konsorsium alami dari sedimen Waduk Jatiluhur menghasilkan konsentrasi gas metana tertinggi. Hasil uji statistik menunjukkan bahwa substrat bungkil jarak dengan rasio C/N 12,6 dan konsentrasi inokulum 20\% menunjukkan hasil yang paling baik. Biogas sudah mulai dihasilkan sejak hari ke-14 meningkat terus sampai akhir pengamatan hari ke-70 dengan total produksi sebanyak 2,822.25 mL dan rata-rata perhari sebanyak 40,31 mL. Dengan analisis GC, kandungan gas metana pada hari ke-49 sudah mencapai $60,57 \% \pm 0,205$ dan terus meningkat sampai hari ke 70 dengan konsentrasi $74,72 \% \pm$ 0,256. Hasil ini dapat digunakan sebagai acuan dalam produksi biogas dengan substrat bungkil Jarak pagar skala aplikasi.
\end{abstract}

Kata kunci: biogas, gas metana, bakteri metanogen, bungkil Jarak Pagar, Jatropha curcas

\begin{abstract}
The study of biogas production with seed pressed cake of Jatropha curcas as a substrate in a $2.5 \mathrm{~L}$ reactor scale aims to obtain methanogenic microbial agents and to know the optimum condition to produce biogas (methane). The research was begun by screening the inoculum source from cowdung, dam sediment, and cow rumen liquid. After the best microbial agents was determined, the next step was the substrate composition using seed press cake of J. curcas with $\mathrm{C} / \mathrm{N}$ ratio of 12,6 and a added with tapioca waste with total $\mathrm{C} / \mathrm{N}$ ratio of 15 . Three variations of inoculum concentrations $(5 \%, 10 \%$, and 20\%) with four times repetitions ware investigated. The system was inoculated with bacterial consortium as started and observed for 70 days by measuring methane production. The result shows that natural consortium from Jatiluhur dam sediment produces the highest methane gas concentration. Seed pressed cake of Jatropha with $\mathrm{C} / \mathrm{N}$ ratio 12.6 and inoculum concentration of $20 \%$ gave the best result. Biogas was produced from 14th day and then increased until 70th day with total production of 2,822.25 mL (average 40.31 $\mathrm{mL}$ per day). GC analysis showed that methane concentration at day 49 th reached $60.57 \%$ and then continued to
\end{abstract}


increase until the 70th day with a concentration of $74.72 \%$. This value is the highest result compared with other achievements reported in literatures. This result can be used as a reference in biogas production with seed pressed cake of J. curcas as a substrate in application scale.

Keywords: biogas, methane, methanogenic bacteria, seed pressed cake,Jatropa curcas.

\section{I.PENDAHULUAN}

Ketergantungan Indonesia terhadap bahan bakar minyak cukup besar. Penggunaan BBM dari tahun ke tahun terus meningkat sedangkan produksi cenderung menurun (Hambali, 2006). Krisis BBM ini dapat diatasi dengan cara mencari sumber energi baru sebagai sumber energi alternatif. Sumber energi alternatif yang sedang dikembangkan dewasa ini adalah biofuel. Hal ini sesuai dengan peraturan presiden no 5 / 2006 tentang kebijakan energi nasional dan instruksi presiden no.1/2006 tentang penyediaan dan pemanfaatan bahan bakar nabati (BBN) (Hambali, 2006).

Biofuel yang sedang dikembangkan saat ini adalah biodiesel. Biodiesel dapat diperoleh dari tumbuhan yang banyak mengandung minyak, seperti Jarak pagar (Jatropha curcas) (Haryadi, 2005).

Pengembangan kebun induk Jarak pagar merupakan program utama pemerintah untuk lima tahun kedepan, dengan asumsi bahwa pada tahun pertama 1 ha lahan terdapat 2500 pohon akan dihasilkan $600 \mathrm{~kg}$ biji jarak/ha dan tahun kelima diharapkan terdapat 2530 ha kebun budidaya (Hambali, 2006).

Pengolahan biji jarak menghasilkan minyak jarak pagar dan bungkil jarak. Bungkil jarak merupakan limbah dari proses pembuatan biodiesel. Pemanfaatan bungkil jarak telah dikembangkan sebagai pupuk organik dan sebagai bahan baku pembuatan briket (Hernas, 2002 ; Republika, 10 Agustus 2006). Namun dengan melihat kandungan bahan organik yang terdapat dalam bungkil jarak ini, masih menyimpan potensi yang besar untuk dikembangkan sebagai bahan baku biogas yang selama ini baru dilakukan dalam tahap penelitian (Hernas, 2002).

Biogas merupakan salah satu sumber energi alternatif yang dapat diproduksi dari berbagai limbah, baik limbah industri, limbah domestik, limbah pertanian maupun limbah peternakan. Komposisi biogas meliputi gas karbondioksida, gas hidrogen, gas nitrogen dan gas metana (Hernas , 2002). Penggunaan bungkil jarak sebagai substrat untuk produksi biogas telah dikembangkan di Nikaragua sejak tahun 1997 (Gubitz,1997), namun sistem biogas dari bungkil jarak ini belum banyak dikembangkan di Indonesia. Untuk menuju skala pilot dalam produksi biogas dari bungkil jarak ini, perlu diadakan penelitian skala laboratorium untuk mengoptimasi mikroorganisme yang terlibat, kondisi lingkungan yang optimum dalam produksi biogas sehingga hasil yang diperoleh dapat digunakan sebagai acuan untuk diaplikasikan pada skala pilot bahkan lebih jauh lagi pada skala industri.

Salah satu faktor yang sangat menentukan dalam proses pembentukan biogas adalah adanya peran serta bakteri, karena pada hakekatnya konversi materi organik menjadi biogas ini merupakan hasil kerja berbagai bakteri yang bekerja secara konsorsium.(Burke, 2001). Proses tidak akan berjalan jika hanya terdapat salah satu bakteri saja, konsorsium memerlukan lebih dari satu spesies bakteri metanogen, ada spesies metanogen yang mampu mengkonversi asetat menjadi metan contoh Thermoacetogenium phaeum, spesies lain mengkombinasikan $\mathrm{CO}_{2}$ dan $\mathrm{H}_{2}$ menjadi metan dan $\mathrm{H}_{2} \mathrm{O}$ melalui proses reduksi karbonat (Fresspatent, 2007) Kondisi reaktor harus benar-benar dijaga agar tetap terjadi keseimbangan sehingga bakteri dapat bekerja secara konsorsium. Bakteri metanogen bersifat anaerob obligat, terbagi menjadi tiga group. Group I Methanobacterium dan Methanobrevibacter, Group II meliputi Methanococcus, dan Group III termasuk genera Methanospirillum dan Methanosarcina. Semuanya ada di ling-kungan air tawar yang anaerob seperti sedimen serta pada saluran pencernaan hewan (Dubey, 2005). Berdasarkan hal tersebut maka sumber 
inokulum yang digunakan pada penelitian ini berasal dari sedimen waduk dan rumen sapi.

\section{METODE PENELITIAN}

Penelitian bersifat eksperimen, desain penelitian yang dipilih adalah RAL (Rancangan Acak Lengkap) dengan tipe faktorial (2x3). Jumlah perlakuan enam dengan jumlah pengulangan empat kali untuk setiap perlakuan. Bahan-bahan yang digunakan adalah bungkil jarak pagar yang diperoleh dari PT Rajawali Nusantara Indonesia Jatitujuh Majalengka. Selain itu digunakan juga onggok (limbah tapioka) sebagai substrat tambahan yang berperan sebagai sumber karbon, diperoleh dari pabrik tapioka di Tasikmalaya. Sumber inokulum konsorsium diperoleh dari cairan rumen sapi yang diambil dari rumah pemotongan hewan Ciroyom, kotoran sapi yang diambil dari peternakan sapi perah di daerah Cimenyan, serta sedimen Waduk Jatiluhur kedalaman 28 meter. Medium pertumbuhan bakteri di laboratorium berupa nutrien agar, Medium selektif metanogen, berbagai medium untuk uji biokimia identifikasi bakteri aerob dan anaerob, berbagai reagen untuk analisis kimia dan biologi.

\subsection{Penapisan Sumber Inokulum konsorsium alami}

Sumber inokulum diperoleh dari cairan rumen sapi, kotoran sapi, sedimen Waduk Jatiluhur. Tahap penapisan sumber inokulum ini dilakukan pada reaktor volume 2,5 liter dengan volume kerja 2 liter. Asupan merupakan campuran substrat bungkil jarak dengan sumber inokulum dimasukkan ke dalam reaktor setiap hari secara bertahap selama 22 hari dengan perbandingan akhir antara padatan (bungkil jarak dan inokulum) dengan air adalah 1:10 (Hernas, 2007). Setelah hari ke-23 reaktor didiamkan selama 14 hari sambil dilakukan pengocokan sebanyak satu kali setiap hari untuk memberi kesempatan bakteri konsorsium bekerja mencerna substrat sehingga menghasilkan gas metana. Hari ke-37 dilakukan uji produksi gas metana dengan cara mencuplik gas menggunakan syringe $1 \mathrm{~mL}$ yang dilengkapi dengan sumbat karet pada ujung jarum, lalu diinjeksikan pada alat kromatografi gas tipe 8A. Uji produksi gas metana dilakukan secara duplo. Inokulum dengan produksi gas metana terbanyak dijadikan sumber inokulum untuk produksi biogas pada tahap perlakuan.

\subsection{Penyiapan Inokulum konsorsium alami}

Inokulum konsorsium alami hasil penapisan dibuat menjadi volume 20 liter dari volume awal 2 liter, dengan cara melakukan penambahan medium berupa medium selektif metanogen secara bertahap sehingga volume menjadi 5 liter, 10 liter, 15 liter sampai 20 liter dengan waktu penambahan setiap 1 minggu. Inokulum konsorsium alami yang digunakan pada tahap perlakuan adalah inokulum volume 20 liter yang sudah diinkubasi selama 30 hari yang digunakan sebagai starter, inkubasi 30 hari bertujuan untuk memberi kesempatan pada bakteri konsorsium berkembang biak dan siap digunakan mencerna substrat pada tahap perlakuan (Anunputtikul \& Rodtong, 2004, dimodifikasi).

\subsection{Penentuan Formulasi Substrat}

Substrat utama yang digunakan adalah Bungkil jarak saja dan bungkil jarak ditambah limbah tapioka. Formulasi substrat dilakukan dengan 2 variasi yaitu bungkil jarak saja dengan rasio $\mathrm{C} / \mathrm{N}$ 12,6 dan bungkil jarak ditambah limbah tapioka dengan rasio C/N 15, penentuan rasio $\mathrm{C} / \mathrm{N}$ berdasarkan komposisi karbon dan nitrogen pada substrat bungkil jarak pagar dan limbah tapioka, dengan perhitungan rasio $\mathrm{C} / \mathrm{N}$ gabungan bungkil jarak dan onggok dihitung dengan rumus sebagai berikut $:$

$\mathrm{C}: \mathrm{N}$ rasio gabungan $=(\% \mathrm{Ca} \times \mathrm{a} \times(1-\mathrm{Ma}))+$ $\underline{((\% \mathrm{Cb} \times \mathrm{b} \times(1}((\% \mathrm{Na} \times \mathrm{a} \times(1-\mathrm{Ma}))+(\% \mathrm{Nb} \times \mathrm{b} \times(1-\mathrm{Mb}))$

Dengan $\mathrm{Ca}, \mathrm{Cb}$ adalah kadar karbon pada bahan a dan bahan b. $\mathrm{Na}$ dan $\mathrm{Nb}$ adalah kadar nitrogen bahan a dan bahan b. Serta Ma dan Mb adalah kadar air bahan a dan bahan b (Bushell, E.,M., \& Slater,1981).

\subsection{Optimasi Konsentrasi Inokulum}

Dari inokulum 20 liter yang telah diinkubasi 30 hari (Anunputtikul \& Rodtong, 2004 dimo- 
difikasi) dilakukan optimasi konsentrasi inokulum menjadi 3 variasi yaitu konsentrasi inokulum 5\% (v/v), 10\% (v/v), 20\% (v/v). Parameter yang diukur meliputi COD, $\mathrm{pH}$, volume gas total, komposisi biogas, jumlah populasi bakteri aerob dan anaerob, perubahan rasio $\mathrm{C} / \mathrm{N}$. Selain itu diamati pula perubahan fisik yang terjadi meliputi bau dan tekstur slurry, uji nyala, jumlah bakteri metanogen pada hari ke-7, hari ke-30 dan hari ke-70 Populasi bakteri aerob dan anaerob selama proses pembentukan biogas dapat dilakukan dengan metode hidrolisis FDA (Fluorescein diasetat). Fluorescein diasetat (3', 6'-diacetylfluorescein) adalah fluorescein yang berkonjugasi dengan dua radikal asetat. Fluorescein diasetat merupakan senyawa yang tidak berwarna. Senyawa ini akan dihidrolisis oleh enzim bebas (eksoenzim) dan enzim intraseluler mikroorganisme, sehingga menghasilkan produk senyawa (fluorescein) yang berwarna, yang secara visual dapat dilihat di dalam sel menggunakan mikroskop fluorescens atau diukur menggunakan spektrofotometer (Green et al., 2006 ; Adam \& Duncan, 2001),). Desain reaktor pada tahap perlakuan diperlihatkan pada gambar 1

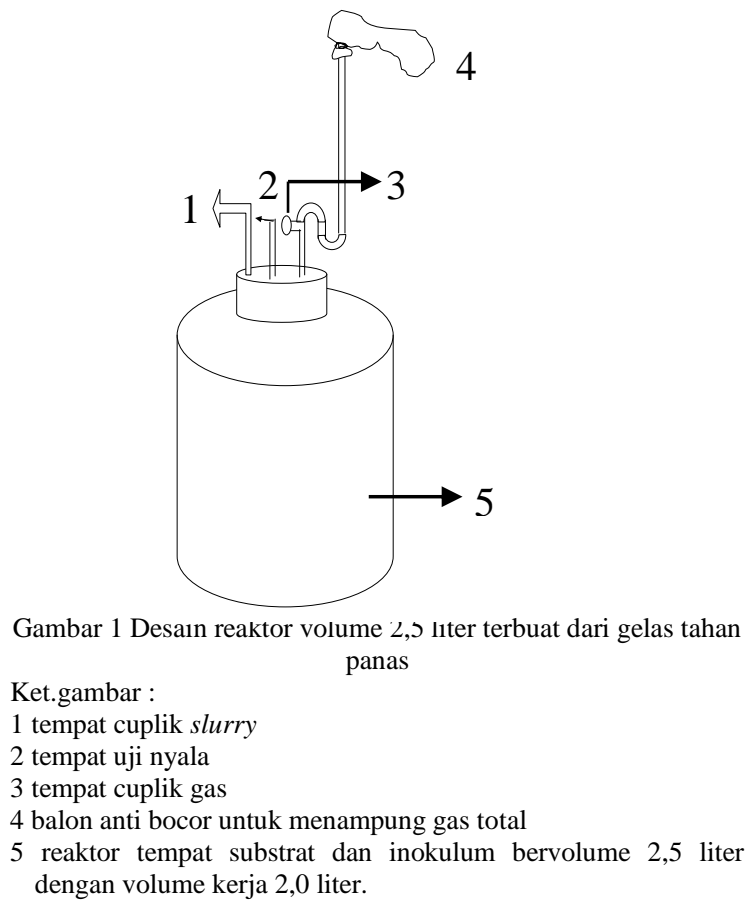

\subsection{Pengukuran Parameter Fisik, Kimia dan Biologi}

Perubahan parameter fisik yang diamati meliputi bau dan tekstur slurry, uji nyala api. Perubahan faktor kimia meliputi COD dengan metode bikromat (Oei \& Reinhard,1989), pH, volume gas total, komposisi biogas dengan menggunakan kromatografi gas Tipe 8A merk Shimatdzu kolom Porapak- Q dan Mulsife 5A.Suhu injektor dan suhu detektor $70^{\circ} \mathrm{C}$, suhu kolom $40^{\circ} \mathrm{C}$, tipe detektor Thermal Conductivity Detector, Laboratorium Met. Perancangan $\&$ Pengendalian Proses Teknik Kimia, ITB). Volume gas total diukur dengan prinsip water displacement (Anunputtikul \& Rodtong, 2004). Faktor biologis meliputi jumlah bakteri aerob dan anaerob dengan menggunakan metode FDA(Green et al., 2005 dimodifikasi).

\section{III.HASIL \& PEMBAHASAN}

\subsection{Hasil Penapisan Bakteri Konsorsium alami}

Penapisan bakteri konsorsium alami dilakukan dari sedimen Waduk Jatiluhur, Kotoran sapi dan cairan rumen sapi. Penapisan dilakukan berdasarkan produksi gas metana yang diukur dengan menggunakan alat kromatografi gas tipe $8 \mathrm{~A}$ pada waktu yang sama yaitu 14 hari. Dari tahap penapisan bakteri konsorsium alami diperoleh hasil uji produksi gas metana yang diperlihatkan pada tabel1.

\begin{tabular}{|c|c|c|c|c|c|}
\hline \multirow{2}{*}{ No } & \multirow{2}{*}{$\begin{array}{l}\text { Sumber } \\
\text { Inokulum }\end{array}$} & \multicolumn{2}{|c|}{$\begin{array}{c}\text { Komposisi gas } \\
\text { metana }(\%)\end{array}$} & \multirow{2}{*}{$\begin{array}{l}\text { Rata- } \\
\text { rata }\end{array}$} & \multirow{2}{*}{ SD } \\
\hline & & $\begin{array}{l}\text { ulangan } \\
1\end{array}$ & $\begin{array}{l}\text { ulangan } \\
2\end{array}$ & & \\
\hline 1 & $\begin{array}{l}\text { Kotoran } \\
\text { sapi }\end{array}$ & 0,25 & 0,54 & 0,399 & 0,206 \\
\hline 2 & $\begin{array}{l}\text { Cairan } \\
\text { rumen } \\
\text { sapi }\end{array}$ & 2,91 & 3,14 & 3,027 & 0,163 \\
\hline 3 & $\begin{array}{l}\text { Sedimen } \\
\text { Waduk } \\
\text { Jatiluhur }\end{array}$ & 6,67 & 7,65 & 7,163 & 0,689 \\
\hline
\end{tabular}

Dari hasil uji produksi gas metana diketahui bahwa produksi gas metana yang paling besar dihasilkan oleh bakteri konsorsium alami yang berasal dari sedimen Waduk Jatiluhur. Sedimen Waduk Jatiluhur menghasilkan gas metana tertinggi dibandingkan kotoran sapi dan rumen 
sapi hal ini disebabkan karena sedimen mengandung populasi mikroorganisme yang melimpah dengan keanekaragaman yang tinggi (Bisset et al., 2007). Menurut Jumiarni (2008) penelitian terbaru menunjukkan hasil enumerasi bakteri aerob dominan yang dapat dikultur dari Waduk Jatiluhur mencapai 1,6 x $10^{8} \mathrm{CFU} / \mathrm{g}$ sedimen sedangkan bakteri anaerob dominan yang dapat dikultur dari sedimen Waduk Jatiluhur dapat mencapai $0,8 \times 10^{7} \mathrm{CFU} / \mathrm{g}$, dengan tingginya bakteri aerob ini dapat membantu menghasilkan asam organik yang tinggi pula yang akan digunakan selanjutnya oleh bakteri metanogen pada proses pembentukan gas metana.Walaupun belum diketahui dengan pasti populasi bakteri metanogen di Waduk Jatiluhur kedalaman 28 meter ini, namun demikian populasi bakteri metanogen dapat mencapai $3 \times 10^{4} / \mathrm{mL}$ di perairan samudera pasifik bagian utara kedalaman 5m - 100m (Madigan et al., 2003), artinya pada kedalaman 28 meter di Waduk Jatiluhur pun dapat mencapai jumlah populasi 3 x $10^{4} / \mathrm{mL}$. Populasi bakteri metanogen dalam cairan rumen menunjukkan angka lebih banyak daripada di perairan dalam, menurut Skillman (2004) dalam Saengkerdsub (2006) menyebutkan bahwa kerapatan bakteri metanogen mencapai $10^{4}-10^{9}$ / gram cairan rumen dalam waktu 1-3 minggu, sedangkan menurut Morvan (1994) dalam Saengkerdsub (2006) ditemukan koloni metanogen dalam cairan rumen dengan kerapatan $10^{6}$ organisme/mL dalam waktu 15 hari. Berdasarkan literatur tersebut dapat diketahui bahwa populasi bakteri metanogen di dalam perairan air tawar lebih sedikit dibanding di dalam cairan rumen sapi, namun pada penelitian ini gas metana yang diukur dan dihasilkan dari sedimen perairan dalam Waduk Jatiluhur dapat lebih banyak daripada cairan rumen sapi dan kotoran sapi, hal ini dapat dijelaskan bahwa menurut Madigan et al. (2003) cairan rumen sapi memiliki komposisi $\mathrm{CO}_{2}$ lebih banyak yaitu $65 \%$ daripada $\mathrm{CH}_{4}$ yang hanya mencapai $35 \%$, hal ini terjadi karena beberapa alasan yaitu karena pertumbuhan bakteri metanogen asetotrof lambat sedangkan waktu tinggal untuk terjadinya konversi asetat menjadi $\mathrm{CH}_{4}$ dalam rumen relatif sedikit, sehingga asetat dalam rumen sapi belum sempat dikonversi menjadi $\mathrm{CH}_{4}$, padahal menurut Ritchie et al. (1997) sekitar $70 \% \mathrm{CH}_{4}$ dapat dihasilkan dari asetat dan $30 \%$ $\mathrm{CH}_{4}$ dihasilkan dari $\mathrm{CO}_{2}$ dan $\mathrm{H}_{2} \mathrm{O}$. Alasan lain metana dihasilkan sedikit pada rumen sapi adalah karena bakteri sintrof pendegradasi asam lemak tidak memegang peran utama dalam rumen. Bakteri sintrof mampu mendegradasi asam lemak seperti propionat dan butirat menjadi asetat, $\mathrm{H}_{2}$ serta $\mathrm{CO}_{2}$ yang akan didegradasi lebih lanjut olehmetanogen menjadi $\mathrm{CH}_{4}$. Namun di dalam rumen sapi, asam lemak ini akan diserap ke dalam aliran darah melalui dinding rumen sehingga tidak sempat diubah oleh bakteri sintrof (Madigan et al., 2003).

\subsection{Pengaruh Konsentrasi inokulum terhadap Produksi Gas metana}

Hasil uji statistik untuk perlakuan konsentrasi inokulum menunjukkan bahwa terdapat perbedaan yang signifikan antara konsentrasi inokulum 5\% dengan $10 \%$ dan $20 \%$ namun tidak terdapat perbedaan yang signifikan antara konsentrasi inokulum $10 \%$ dengan $20 \%$, selengkapnya rata-rata produksi gas metana pada perlakuan konsentrasi inokulum dan rasio $\mathrm{C} / \mathrm{N}$ ditampilkan pada gambar 2

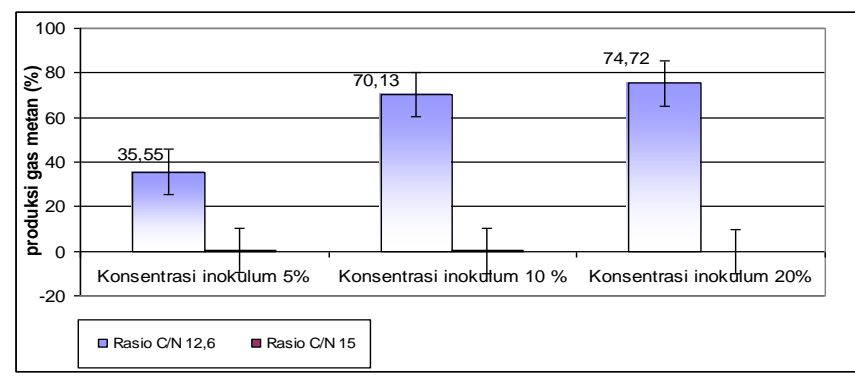

Gambar 2 Produksi Gas Metana Hari ke-70 pada Perlakuan Rasio C/N dan Konsentrasi Inokulum

Walaupun secara statistik tidak terdapat perbedaan produksi gas metana antara konsentrasi inokulum $10 \%$ dan $20 \%$, namun jika dianalisis produksi gas metana pada minggu ke-7 sampai minggu ke-10 tampak bahwa perlakuan konsentrasi inokulum 20\% menunjukkan hasil yang lebih stabil, seperti yang tampak pada tabel 2 . 
Tabel 2 Perbandingan produksi gas metana minggu ke-7 dan minggu ke-10 pada masing-masing perlakuan

\begin{tabular}{|c|c|c|c|c|c|c|}
\hline \multirow[t]{2}{*}{ no } & $\begin{array}{c}\text { optimasi } \\
1\end{array}$ & optimasi 2 & $\begin{array}{l}\text { produksi } \\
\text { gas total/ }\end{array}$ & $\begin{array}{l}\text { Produksi } \\
\text { gas total/ }\end{array}$ & $\begin{array}{c}\text { produksi } \\
\text { gas } \\
\text { metana }(\%)\end{array}$ & $\begin{array}{c}\text { Produksi } \\
\text { gas } \\
\text { metana } \\
(\%)\end{array}$ \\
\hline & $\begin{array}{l}\text { Rasio } \\
\text { C/N } \\
\text { substrat }\end{array}$ & $\begin{array}{l}\text { konsentrasi } \\
\text { inokulum }\end{array}$ & hari (mL) & $\begin{array}{l}\text { hari } \\
(\mathrm{mL})\end{array}$ & $\begin{array}{c}\underset{\text { ke-7 }}{\operatorname{minggu}} \\
\text { e }\end{array}$ & $\begin{array}{c}\text { minggu } \\
\text { ke-10 }\end{array}$ \\
\hline 1 & 12,6 & $5 \%$ & 2479,25 & 35,42 & $\begin{array}{c}53,65 \pm \\
0,08\end{array}$ & $\begin{array}{c}35,44 \pm \\
0,11\end{array}$ \\
\hline & & & & & $46,41 \pm$ & $70,13 \pm$ \\
\hline 2 & 12,6 & $10 \%$ & 2674,75 & 38,21 & 0,05 & 0,11 \\
\hline 3 & 12,6 & $20 \%$ & 2822,25 & 40,30 & $\begin{array}{c}60,57 \pm \\
0,20\end{array}$ & $\begin{array}{c}74,72 \pm \\
0,25\end{array}$ \\
\hline 4 & 15 & $5 \%$ & 1434,25 & 20,49 & 0 & 0 \\
\hline 5 & 15 & $10 \%$ & 1392,25 & 19,90 & 0 & 0 \\
\hline 6 & 15 & $20 \%$ & 1506,75 & 21,50 & 0 & 0 \\
\hline
\end{tabular}

Chemical oxygen demand atau kebutuhan oksigen kimia (KOK) merupakan jumlah oksigen dalam $\mathrm{mg} \mathrm{O}_{2}$ yang diperlukan untuk mengoksidasi zat-zat organik (Oei \& Reinhard, 1989).Perubahan COD selama proses fermentasi menunjukkan adanya penggunaan materi organik yang terkandung dalam substrat untuk dikonversi menjadi gas metana. Dari gambar 3 dapat diketahui bahwa pada perlakuan rasio $\mathrm{C} / \mathrm{N}$ 12,6 menunjukkan adanya perubahan materi organik yang cukup baik karena sistem biogas berjalan dengan baik, sehingga gas metana yang dihasilkan banyak.

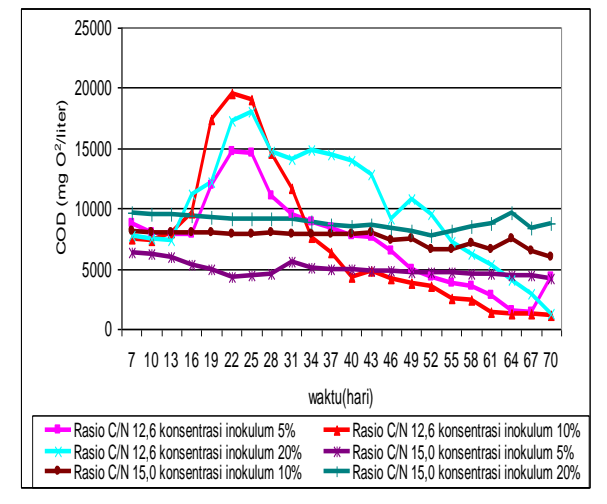

Gambar 3 Grafik Perubahan COD selama Proses Fermentasi , pH awal 8

Materi organik pada hari ke 22-25 cenderung naik sebelum akhirnya turun kembali, hal ini ada hubungan dengan semakin meningkatnya jumlah bakteri anaerob yang bersifat autotrof pada hari ke-25. Bakteri autotrof merupakan bakteri anaerob yang mampu menggunakan $\mathrm{CO}_{2}$ sebagai akseptor elektron. Adanya Bakteri homoasetogen dan metanogen yang mereduksi $\mathrm{CO}_{2}$ menjadi asetat dan $\mathrm{CH}_{4}$ menyebabkan adanya senyawa intermediet yang larut dalam slurry sehingga ketika dilakukan analisis COD, oksigen yang ada dalam kalium bikromat akan mengoksidasi senyawa-senyawa intermediet tersebut sehingga meningkatkan nilai COD.

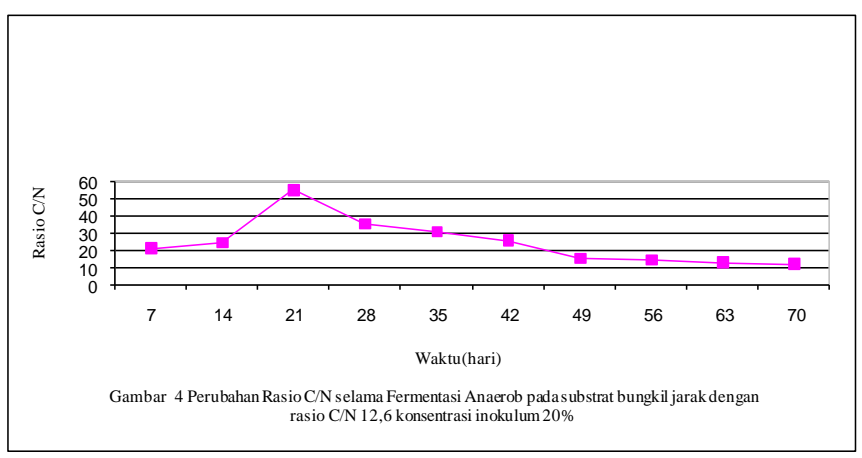

Konversi asetat oleh golongan asetotrof metanogen menjadi $\mathrm{CH}_{4}$ menyebabkan nilai COD menjadi menurun kembali. Pola ini sesuai dengan perubahan rasio $\mathrm{C} / \mathrm{N}$ yang juga diukur selama proses fermentasi anaerob pada reaktor yang menggunakan substrat bungkil jarak konsentrasi inokulum $20 \%$. Perubahan rasio $\mathrm{C} / \mathrm{N}$ yang diamati selama proses fermentasi anaerob ditampilkan pada gambar 4 .

\section{SIMPULAN\& SARAN}

4.1 Hasil yang diperoleh menunjukkan bahwa :

1. Inokulum yang menghasilkan produksi gas metana tertinggi adalah inokulum bakteri konsorsium alami dari Waduk Jatiluhur dengan rata-rata produksi gas metana yang dihasilkan adalah $7,163 \% \pm$ 0,689 .

2. Substrat yang menghasilkan gas metana tertinggi adalah substrat bungkil jarak tanpa campuran limbah tapioka dengan rasio $\mathrm{C} / \mathrm{N}$ substrat 12,6 dengan hasil $74,72 \% \pm 0,256$.

3. Konsentrasi inokulum yang menghasilkan gas metana tertinggi adalah konsentrasi inokulum 20\%, komposisi gas metana lebih stabil dari hari ke-49 sampai hari ke-70 yaitu rata-rata $60,57 \%$ $\pm 0,205 \mathrm{~s} / \mathrm{d} 74,72 \% \pm 0,256$ dengan produksi gas total sebanyak $2,822,25 \mathrm{~mL}$ dan rata-rata produksi biogas perhari sebanyak 40,31 mL. 


\subsection{Saran}

1. Diperlukan penelitian lebih lanjut dengan substrat yang sama namun pada volume yang lebih besar dengan sistem kontinyu.

2. Dilakukan identifikasi Bakteri Metanogen dominan yang dapat dikultur dari Slurry hasil fermentasi anaerob.

\section{DAFTAR PUSTAKA}

Adam, G., \& Duncan, H. (2001), Development of a sensitive and rapid method for the measurement of total microbial activity using fluorescein diacetate (FDA) in a range of soils, Soil Biology \& Biocemistry, 33, 943 - 951.

Anunputtikul, W., \& Rodtong, S. (2004 ), The Joint International conference on " Sustainable Energy and Environment (SEE)". Laboratory Scale Experiment for Biogas Production from Cassava Tubers. : Hua Hin, Thailand.

Anonim (1995),Standard Test Methods for Moisture, Ash, and Organic Matter of Peat and Other Organic Soils. Designation: D2974-87. ASTM. Committee

Anonim (1996), Blending Materials for the Composting Process. Composting Factsheet. British Columbia. Ministry of Agriculture Food and Fisheries.

Anonim (2005), Pemanfaatan limbah menjadi sumber energi alternatif, Surat Kabar Kompas, 17 Maret 2005.

Anonim (2006),Dari pupuk hingga briket, Surat Kabar Republika, 10 Agustus 2006.

Bissett, A., Burke, C., Cook, P.L.M., \&Bowman, J.P. (2007), Bacterial community shifts in organically perturbbedsediments, Environmental Microbiology, 9 (1), 46-60.
Bushell, E.,M., \& Slater, J.H.(1981), Mixed Culture Fermentations, Society for General Microbiology by Academik Press., University of Surrey

Burke, D.A. (2001), Dairy Waste Anaerobic Digestion Handbook. Environmental Energy Company, Hill Street Olympia. Dalam situs http//www.makingenergy. com.

Cappuccino, J.G., \& Sherman, N. (2005), Microbiology a Laboratory Manual, $7^{\text {th }}$ Ed, The Benjamin/Cummings Publishing Company, Inc. San Francisco

Dubey, S.K. (2005), Microbial ecology of methane emission in rice agroecosystem, Applied Ecology and Environmental Research, 3(2), 1-27.Dalam situs :http//www.ecology.kee.hu/pdf/0302_ 001027.pdf.

Green, V. S., Stott, D.E., \& Diack, M. (2005), Assay for fluorescein diaceate hydrolitic activity : optimization for soil sampes, Soil Biol. \& Biochem., 38, 693 - 701

Gubitz, M.G., Mittelbach., \& Trabi, M. (1997), Biofuel and Industrial Products from Jatropha curcas. Developed from the Symposium Jatropha curcas 97, Managua, Nicaragua.

Hammond, S.M., Lambert, P.A., \& Rycroft, A.N. (1984), The Bacterial Cell Surface, Croom Helm Ltd., Sydney, 226 hal.

Holt, J.G., Krieg, N.R., Sneath, P.H.A., Staley, J.T., \& Williams, S.T. (1994), Bergey's Manual of Determinative Bacteriology, $9^{\text {th }}$ ed., The Williams \& Wilkins Co., Inc., USA.

Hurst,C.J., Knudsen,G.R., Mclnerney, M.J., Stetzenbach,L.D., \& Walter, M.V.(2005), Manual of environmental microbiology. ASM Press, Washington D.C. 
Hernas, T., Brodjonegoro,T.P., \& Reksowardjojo, I.K. (2002),Jarak Pagar sang Primadona. Dalam situs http://www. pikiran-rakyat.com/cetak/2005/1005/13/ cakrawala/index.htm.

Haryadi. (2005), Budidaya Tanaman Jarak (Jatrophs curcas, L)sebagai Sumber Bahan Alternatif Biofuel. Dalam situs http// www. ristek.go.id.

Hambali , E., Muzdalifah, S., Sulistyanto, G., \& Lesmana, T.(2006), Diversifikasi Produk olahan Jarak Pagar \& Kaitannya dengan CSR Perusahaan Swasta di Indonesia. Eka Cipta Foundation, Bogor.

Hernas,T., Kelompok Riset Biodiesel ITB. (2007),Biogas dari Bungkil Jarak Pagar , inovasi terbaru dari teknik Kimia ITB. ITB News.

Jumiarni, D. (2008). Kajian mikrobiologi sedimen waduk saguling, cirata dan jatiluhur (Jawa Barat): Potensi sedimen sebagai pupuk. Tesis. Program Pascasarjana. Institut Teknologi Bandung.

Kussmaul, M., Wilimzig, M., \& Bock, E. (1998), Methanotrophs and methanogens in Masonry. Applied and environmental microbiology. 64 (11).4530-4532

Kossmann,W., Habermehl,S., Hoerz,T., Kramer,P., Klingler,C., Wittur,T., \&Euler, K.H.(1997), Biogas Digest Volume 1,Biogas Basics. Infprmation and Advisory Service on Appropriate Technology. 1-49.

Lay, Bibiana.W. (1994), Analisis Mikroba di Laboratorium. P.T Raja Grafindo Persada, Jakarta.

Mink, W.R., \& Dugan, R.P. (1976), Tentative Identification of Metanogenic Bacteria by Fluorescence Microscopy. Applied Microbiology. American Society for Microbiology.33 (3). 713-717.
Montaldi, F.A., \&Roth, I.L. (1990), Parasporal Bodies of B.laterosporus Sporangia. Bacteriol. 172 (4). 2168-2171. Dalam situs:http//www.pubmedcentral.nih.gov.

Madigan, M.T., Martinko, J.M., \&Parker, J.(1997),Biology of Microorganisms. Prentice Hall International., USA.

Madigan, M.T., Martinko, J.M.\& Parker, J. (2003),Biology of Microorganisms, $9^{\text {th }}$ Ed, Pearson Education, Inc., USA.

Maier, R.M., Pepper, I.L., \& Gerba, C.P. (2003), Environmental Microbiology, Academic Press, San Diego.

Makoi, J.H.J.R., \& Ndakidemi, P.A. (2008), Selected soil enzymes : examples of their potential roles in the ecosystem, African Journal of Biotechnology, 7 (3), 181 191.

Nakatsugawa, N., \& Horikoshi, K. (1992), Alkalophilic methanogen and fast methane fermentation method. United States Patent 5143835. Dalam situs http://freepatentsonline.com/5143835.ht $\mathrm{ml}$.

Nojiri, M., \& Saito, T. (1997), Structure and Function of Poly(3-Hydroxybutyrate) Depolymerase from Alcaligenes faecalis T1,Journal of Bacteriology. American Society for Microbiology, 179 (22). 69656970.

Oei, B. L., \& Reinhard, J. (1989), Metode Analisa pada Fermentasi Anaerob.Pusat Antar Universitas Bioteknologi Institut Teknologi Bandung.

Priyanto, U.(2007), Menghasilkan biodiesel jarak pagar berkualitas. Agromedia Pustaka. Jakarta.

Peck, M.W. (1989), Change in Concentration of Coenzyme $\mathrm{F}_{420}$ Analogs during Batch Growth of Methanosarcina barkeri and Methanosarcina mazei, Applied and 
Environmental Microbiology, 35(4). 940945.

Ritchie, D.A., Edwards, C., Mc Donald, I.R., \&Murrell, J.C. (1997), Detection of Metanogen \& Methanotrophs in Natural Environment, Global Change Biology, 3, 339-350.

Rao, N.S.S. (1982), Biofertilizer in Agriculture, A.A. Balkema, Rotterdam.

Rao, N.S.S. (1994), Mikroorganisme Tanah dan Pertumbuhan Tanaman, Edisi kedua, UI-Press,Jakarta.

Stevenson, J.R.(2008), General Microbiology. Archaeal Diversity Study Guide.mht.

Schnurer, J., \& Rosswall, T. (1982), Fluorescein diacetate hydrolysis as a measure of total microbial activity in soil and litter, Applied and Environmental Microbiology, 43 (6), 1256 - 1261.
Saengkerdsub, S. (2006), Establisment, Identification, quantification of Metanogenic Archaea in Chicken Ceca and Metanogenesis Inhibition in in Vitro Chicken Ceca by Using Nitrocom Pound, Thesis, A \& M University, Texas.

Urakawa, H., Tsukamoto, K., \&Ohwada, K. (1999), Microbial diversity in marine sediments fromSagami Bay and Tokyo Bay, Japan, asdetermined by 16S rRNA gene analysis, Microbiology, 145, 33053315.

Umerie, S.C., Ekwealor, A.L., \& Nwagbo, L.O.(2000), Lysine Production by B.laterosporus from various Carbohydrates \& Seed Meals. Departement of Science Technology, Nnamdi Azikiwe University.Nigeria. Dalam situs : http//www. Sciencedirect. com/science 